ENTREPRENEURSHIP AND SUSTAINABILITY ISSUES

ISSN 2345-0282 (online) http://jssidoi.org/jesi/

2018 Volume 6 Number 4 (June)

http://doi.org/10.9770/jesi.2019.6.4(5)

\title{
ARE THE MOTIVATIONAL PREFERENCES OF EMPLOYEES WORKING IN SMALL ENTERPRISES IN SLOVAKIA CHANGING IN TIME?*
}

\author{
Silvia Lorincová ${ }^{1}$, Miloš Hitka ${ }^{2}$ Ĺubica Bajzíková ${ }^{3}$, Dagmar Weberová ${ }^{4}$ \\ 1,2 Faculty of Wood Sciences and Technology, Technical University in Zvolen, T. G. Masaryka 24, 96053 Zvolen, Slovakia \\ ${ }^{3}$ Faculty of Management, Comenius University in Bratislava, Odbojárov 10, P.O.BOX 95, 82005 Bratislava 25, Slovakia \\ ${ }^{4}$ Faculty of Multimedia Communications, Tomas Bata University in Zlin, Univerzitni 2431, 76001 Zlín, Czech Republic \\ E-mails: ${ }^{1}$ silvia.lorincova@tuzvo.sk $;{ }^{2}$ hitka@tuzvo.sk $;{ }^{3}$ lubica.bajzikova@fm.uniba.sk $;{ }^{4}$ weberova@utb.cz
}

Received 10 December 2018; accepted 18 April 2019; published 30 June 2019

\begin{abstract}
Small and medium-sized enterprises constitute a significant part of Slovakia's economy with the greatest potential for growth and the impact on economic stabilization and balanced development of the regions. The employee motivation has a major impact on the performance of employees working in these businesses. Research focused on the exploration of employee motivational preferences was conducted in all regions of Slovakia in 2017 and 2018. The sociological survey method was used through anonymous questionnaires. Overall, 2,646 respondents participated in the research. Based on the research results, it can be stated, that motivational preferences of employees working in small enterprises in Slovakia are changing over time. These are primarily motivational factors relating to the social needs and financial motivational factors.
\end{abstract}

Keywords: employee motivation; small and medium-sized enterprises; Slovakia

Reference to this paper should be made as follows: Lorincová, S.; Hitka, M.; Bajzíková, L.; Weberová, D. 2019. Are the motivational preferences of employees working in small enterprises in Slovakia changing in time, Entrepreneurship and Sustainability Issues 6(4): 1618-1635. https://doi.org/10.9770/jesi.2019.6.4(5)

JEL Classifications: J24, M12, O15

\section{Introduction and theoretical background}

\footnotetext{
* This research was supported by the project, which has received funding from VEGA 1/0024/17 Computational model of motivation. This research was supported by the project APVV 16-0297 Updating of anthropometric database of Slovak population, and VEGA 1/0320/17 Economic and social context of European 20/20/20 targets from the viewpoint of economy low-energy houses.
}
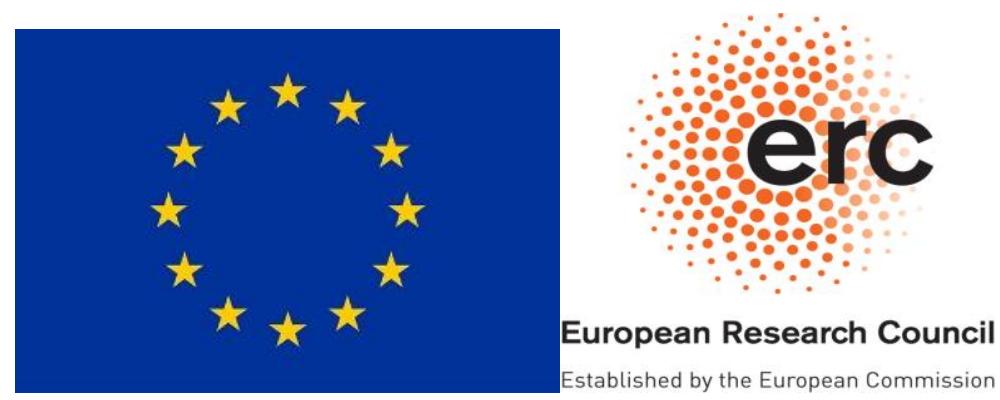
ENTREPRENEURSHIP AND SUSTAINABILITY ISSUES

ISSN 2345-0282 (online) http://jssidoi.org/jesi/

2019 Volume 6 Number 4 (June)

http://doi.org/10.9770/jesi.2019.6.4(5)

Small and medium-sized enterprises (SMEs) constitute a significant part of Slovakia's economy with the greatest potential for growth and the impact on economic stabilization and balanced development of the regions (Marková et al. 2016; Lesáková et al. 2017; Mura et al. 2018). In Slovakia, SMEs present $99.9 \%$ of the total number of business entities. They offer a number of benefits that large companies are not usually able to provide. The most important are their flexibility, quick response to changes in the environment, ease of decision making, and high market focus (Altinay et al. 2016; Němec et al. 2017; Prange et al. 2017; Sertic et al. 2018; Žul'ová et al. 2018). They also provide employment opportunities for almost three quarters of the active workforce and contribute more than half to creating added value. Thanks to their rapid adaptation to the changing environment and customer needs, small businesses are the carriers of many small innovations (Georgiadis et al. 2012; Jonec et al. 2013; Havierniková et al. 2017; Carreras et al. 2018; Kovalova et al. 2018; Mura \& Mazák, 2018). In 2017, the small and medium-sized enterprise (SME) sector developed under conditions of increasing performance of the Slovak economy. Almost all main indicators characterizing the development of SMEs recorded a positive development. SMEs recorded increased employment $(+1.4 \%)$, added value $(+8.9 \%)$, or profit $(+7.5 \%)$, while value added growth in the SME sector was the most significant within the last seven years. However, in the foreign trade area, improvement has not been achieved in the SME sector (Slovak Business Agency 2018).

The performance of these businesses is affected by a number of specific processes (Lesáková 2012; Bielikova et al. 2014; Diaz-Fernandez et al. 2015; Poliacikova 2015; Salyova et al. 2015; Straková et al. 2016; Malá et al. 2017; Musa et al. 2017; Ližbetinová 2017; Urbancova et al. 2017; Aydın et al. 2018; Matraeva et al. 2018; Schouten, 2019). One of them is employee motivation, which is considered a powerful tool to strengthen and trigger the employee's desire to work (Dobre 2013; Cseh Papp et. al., 2018). It is the willingness of the individual to make a special effort to achieve the stated goal and at the same time the willingness of the employee to spend the necessary time to achieve this goal. Weihrich and Koontz (1993) perceive motivation as a cycle where, initially, there is a sense of need that creates wishes. They stimulate the creation of activities that are aimed at fulfilling the desired wishes, which again creates space for the emergence of new needs.

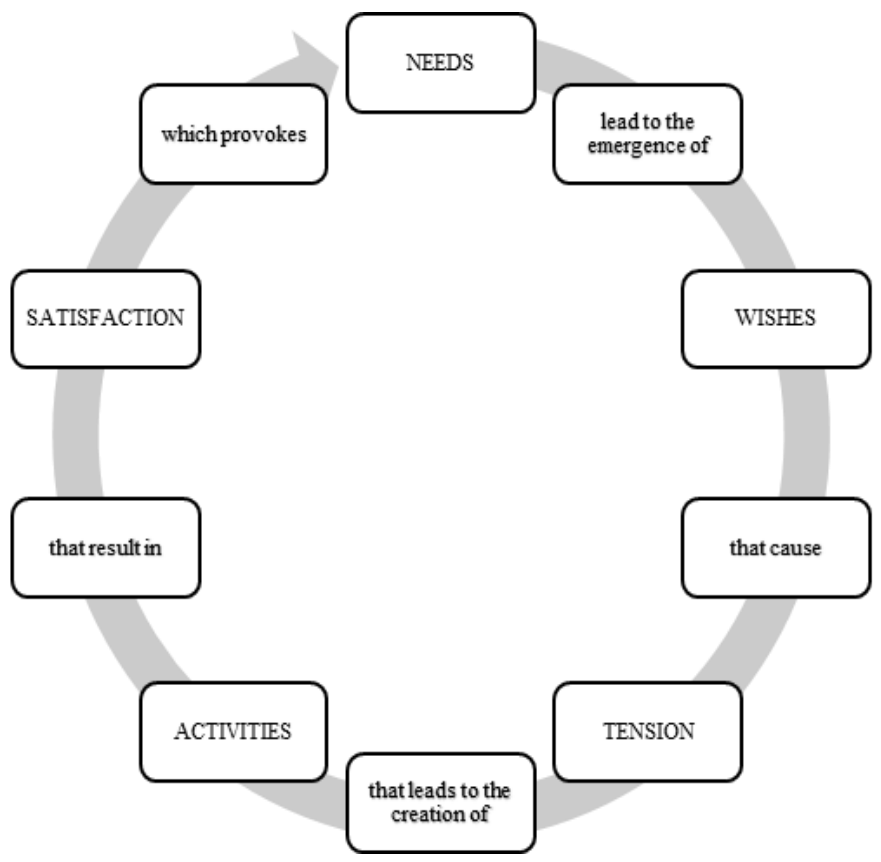

Fig.1. Chain: Need - Desire - Satisfaction Source: Koontz et al. 1993 


\section{ENTREPRENEURSHIP AND SUSTAINABILITY ISSUES}

ISSN 2345-0282 (online) http://jssidoi.org/jesi/

2019 Volume 6 Number 4 (June)

http://doi.org/10.9770/jesi.2019.6.4(5)

Denhardt et al. (2013) are of the opinion that if there is a sufficient number of employees in the company who are willing to work more than expected, then they will achieve higher performance. At the same time, employees are willing to work as long as they know their work performance will be appreciated. According to recent studies (Grossbart 2006; Campbell et al. 2007; Christianson et al. 2008; Eisenberger et al. 2009; Van Herck et al. 2010; $\mathrm{Xu}$ et al. 2017), one of the most used motivational factors that is used in practice is money. In addition, the research carried out by Al-Belushi et al. (2017) was also focused on the importance of monetary rewarding as a motivational factor. The results show that, in the opinion of $76.1 \%$ of respondents, the financial stimulus is important. It also follows from the cited research that $73.9 \%$ of the respondents stated that the wage affects their motivation. Most respondents agree that attractive pay increases their motivation to work. Research has further shown that monetary motivation has a direct impact on the willingness to achieve higher performance. This is confirmed by the research of Kuranchie-Mensah et al. (2016), Carr et al. (2017), Haar et al. (2018), Mészáros (2018) and Chang et al. (2018), which suggest that wages can have a positive impact on an employee's internal motivation by promoting autonomy and self-reliance. In many cases, however, managers make the most common mistake. They mistakenly think that every employee is motivated only by money.

According to Herzberg (1987), the basis of successful motivation is praise, which should come at a reasonable distance from the praised performance, always in an adequate manner that is in compliance with the attributes of praise. In order to praise in an effective way, it should not be repeated as it degrades its value. The importance of praise is confirmed by the research by Al Tareq et al. (2017). Authors say that praise will strengthen the position and recognition of the employee in the enterprise, which results in an increasing motivation to work. The same findings are presented by Belohlavek et al. (2003), based on the reseach, the awareness of success encourages and delivers a new taste and thrill. The importance of feedback on a fair assessment of employee performance is highlighted by Kozjek and Ovsenika (2017). Research results also show that feedback (without monetary reward) has a significant motivational effect on the employee and leads to long-term motivation. According to Al-Belushi et al. (2017), the growth of employees towards professional development leads to increasing performance and motivation of employees. Current research studies (Kropivšek et al. 2011; Fakhrutdinova et al. 2013; Damij et al. 2015; Kamasheva et al. 2015; Minarova 2015; Ližbetinová et al. 2016; Myint et al. 2016; Vetráková et al. 2016; Wang 2016; Pingping 2017; Bogdanović et al. 2018; Borisov et al. 2018) have shown that there is a number of factors that motivate employees. At the same time, however, the set of motivational factors is changing in time, this happens due to knowledge, age, education, experience, environment and so on (Armstrong 2007). In this context, it is the task of managers to choose such an m program that appropriately ensures maximum performance of employees.

\section{Materials and methods}

Research focused on the exploration of employee motivational preferences was conducted in all regions of Slovakia in 2017 and 2018. The sociological survey method through anonymous questionnaires was used. Using the random selection method, questionnaires were distributed to employees working in small enterprises.

European Commission Recommendation No. 2003/361/EC defines a small enterprise as an enterprise which employs fewer than 50 persons and whose annual turnover and /or annual balance sheet total does not exceed EUR 10 million.

Total of 1,227 respondents participated in the research in 2017. In 2018, a total of 1,419 respondents participated in the research. A more detailed structure of the research sample is presented in Table 1. 
ENTREPRENEURSHIP AND SUSTAINABILITY ISSUES

ISSN 2345-0282 (online) http://jssidoi.org/jesi/

2019 Volume 6 Number 4 (June)

http://doi.org/10.9770/jesi.2019.6.4(5)

Table 1. Structure of the research sample

\begin{tabular}{|l|c|c|c|c|}
\hline \multirow{2}{*}{ Data to identify respondents } & \multicolumn{2}{|c|}{$\mathbf{2 0 1 7}$} & \multicolumn{2}{c|}{$\mathbf{2 0 1 8}$} \\
\cline { 2 - 5 } & Absolute frequency & Relative frequency & Absolute frequency & Relative frequency \\
\hline Gender & 705 & 57.46 & 827 & 58.28 \\
\hline Male & 522 & 42.54 & 592 & 41.72 \\
\hline Female & \multicolumn{5}{|l|}{} \\
\hline Age & 268 & 21.84 & 237 & 16.70 \\
\hline Up to 30 years & 432 & 35.21 & 435 & 30.66 \\
\hline 31-40 years & 366 & 29.83 & 423 & 29.81 \\
\hline 41-50 years & 161 & 13.12 & 324 & 22.83 \\
\hline 51 years and more & \multicolumn{5}{|l|}{} \\
\hline Completed education & 33 & 2.69 & 21 & 1.48 \\
\hline Primary & 212 & 17.28 & 177 & 12.47 \\
\hline Lower secondary & 634 & 51.67 & 686 & 48.34 \\
\hline Upper secondary & 348 & 28.36 & 535 & 37.71 \\
\hline Higher & \multicolumn{5}{|l|}{} \\
\hline Seniority & 114 & 9.29 & 81 & 5.71 \\
\hline Less than 1 year & 338 & 27.55 & 288 & 20.30 \\
\hline 1-3 years & 300 & 24.45 & 236 & 23.68 \\
\hline 4-6 years & 227 & 18.50 & 252 & 17.76 \\
\hline 7-9 years & 248 & 20.21 & & 32.55 \\
\hline 10 years and more
\end{tabular}

Source: Own research

Respondents used a five-point rating scale $(5=$ very important, $4=$ important, $3=$ medium important, $2=$ less important, 1 = unimportant). 30 motivational factors shown in Table 2 were evaluated. For reasons of not influencing the respondents, motivational factors were arranged alphabetically.

Table 2. The analyzed motivational factors

\begin{tabular}{|c|c|c|c|}
\hline No. & Motivational factors & No. & Motivational factors \\
\hline 1. & Atmosphere in the workplace & 16. & Prestige \\
\hline 2. & Good work team & 17. & Supervisor's approach \\
\hline 3. & Fringe benefits & 18. & Individual decision-making \\
\hline 4. & Physical effort at work & 19. & Selfactualization \\
\hline 5. & Job security & 20. & Social benefits \\
\hline 6. & Communication in the workplace & 21. & Fair appraisal system \\
\hline 7. & Name of the company & 22. & Stress \\
\hline 8. & Opportunity to apply one's own ability & 23. & Mental effort \\
\hline 9. & Workload and type of work & 24. & Mission of the company \\
\hline 10. & Information about performance result & 25. & Region's development \\
\hline 11. & Working hours & 26. & Personal growth \\
\hline 12. & Work environment & 27. & Relation to the environment \\
\hline 13. & Job performance & 28. & Free time \\
\hline 14. & Career advancement & 29. & Recognition \\
\hline 15. & Competences & 30. & Base salary \\
\hline
\end{tabular}

Source: Own research 
Due to the scope and independence of the sample sets, we tested the zero hypothesis on average equivalence values of motivational preferences according to time (year 2017 and 2018) using the dual choice t-test for independent selections. Basic statistical characteristics were calculated for each motivational factor. These include information about the properties of the basic researched sets using fewer numeric data. In addition to the simple comparison of the values of the basic characteristics, due to the selective character of the obtained data, the conformity of the arithmetic means was tested. In the Student's t-test, we examined the significance of differences in the arithmetic mean of the individual motivational factors in the monitored enterprises so that it was excluded at the chosen level of significance $\alpha$ that the observed differences between the arithmetic mean were not due solely to the representation error. Each motivational factor was summarily described by the basic characteristics of the level and variability of the quantitative features - the arithmetic mean $\bar{x}$, the standard deviation $s_{x}$ and the coefficient of variation. Consequently, the results were compared. Testing was performed at the significance level $\alpha=0.05$. Then a working hypothesis was defined:

- $\mathrm{WH}_{1}-\mathrm{We}$ assume that motivational preferences of employees working in small enterprises in Slovakia do not change over time.

As a test criterion, a random variable $t$ was used which had Student's t distribution in the form:

- if $\mu_{12}=\mu_{22} ; X_{1}$ and $X_{2}$ are independent

$$
t=\frac{\bar{x}_{1}-\bar{x}_{2}}{\sqrt{\frac{n_{1} \cdot s_{1}^{2}+n_{2} \cdot s_{2}^{2}}{n_{1}+n_{2}-2} \cdot \frac{n_{1}+n_{2}}{n_{1} \cdot n_{2}}}}
$$

- $\quad$ if $\mu_{12} \neq \mu_{22} ; X_{1}$ and $X_{2}$ are independent

$$
t=\frac{\bar{x}_{1}-\bar{x}_{2}}{\sqrt{\frac{s_{1}^{2}}{n_{1}-1}+\frac{s_{2}^{2}}{n_{2}-1}}}
$$

Subsequently, using cluster analysis, Euclidean distance (Triola 1989; Mason et al. 1990; Scheer et al. 2014) the similar groups of motivational factors preferred by employees working in small enterprises in Slovakia are identified. The Euclidean distance is given:

$$
\left(x_{1}, x_{2}\right)=\sqrt{\sum_{i=1}^{n}\left(x_{1 i}-x_{2 i}\right)^{2}}
$$

where:

- $\quad x_{1 i}$ - the value of the $\mathrm{i}$-th variable on the object 1

- $\quad x_{2 i}$ - the value of the $\mathrm{i}$-th variable on the object 2

- $\quad n$ - number of variables.

Subsequently, the second working hypothesis was defined:

- $\mathrm{WH}_{2}-\mathrm{We}$ assume that the groups of motivational factors preferred by employees working in small enterprises in Slovakia do not change over time. 
ENTREPRENEURSHIP AND SUSTAINABILITY ISSUES

ISSN 2345-0282 (online) http://jssidoi.org/jesi/

2019 Volume 6 Number 4 (June)

http://doi.org/10.9770/jesi.2019.6.4(5)

\section{Results and discussion}

When comparing the level of motivational preferences of employees working in small enterprises in 2017 and 2018, we can see changes in the order of the average values of the analyzed motivational factors (Table 3). Overall, there is a decrease in the level of employee motivational preferences in 2018 (Figure 2).

Table 3. Ranking of the importance of motivational preferences of employees working in small enterprises in Slovakia in 2017 and 2018

\begin{tabular}{|c|c|c|c|c|}
\hline No. & Motivational factors & 2017 & Motivational factors & 2018 \\
\hline 1. & Base salary & 4.59 & Good work team & 4.51 \\
\hline 2. & Atmosphere in the workplace & 4.55 & Atmosphere in the workplace & 4.50 \\
\hline 3. & Good work team & 4.53 & Supervisor's approach & 4.48 \\
\hline 4. & Fringe benefits & 4.45 & Fringe benefits & 4.47 \\
\hline 5. & Supervisor's approach & 4.43 & Fair appraisal system & 4.47 \\
\hline 6. & Job security & 4.40 & Job security & 4.39 \\
\hline 7. & Fair appraisal system & 4.39 & Communication in the workplace & 4.38 \\
\hline 8. & Communication in the workplace & 4.35 & Social benefits & 4.30 \\
\hline 9. & Working hours & 4.29 & Working hours & 4.29 \\
\hline 10. & Work environment & 4.26 & Work environment & 4.26 \\
\hline 11. & Social benefits & 4.24 & Job performance & 4.19 \\
\hline 12. & Job performance & 4.22 & Workload and type of work & 4.18 \\
\hline 13. & Free time & 4.20 & Career advancement & 4.14 \\
\hline 14. & Recognition & 4.19 & Selfactualization & 4.13 \\
\hline 15. & Workload and type of work & 4.15 & Opportunity to apply one's own ability & 4.11 \\
\hline 16. & Information about performance result & 4.11 & Individual decision-making & 4.11 \\
\hline 17. & Stress & 4.11 & Information about performance result & 4.09 \\
\hline 18. & Opportunity to apply one's own ability & 4.10 & Stress & 4.05 \\
\hline 19. & Name of the company & 4.09 & Competences & 3.98 \\
\hline 20. & Career advancement & 4.09 & Physical effort at work & 3.92 \\
\hline 21. & Personal growth & 4.07 & Name of the company & 3.91 \\
\hline 22. & Individual decision-making & 4.05 & Prestige & 3.81 \\
\hline 23. & Selfactualization & 4.05 & Relation to the environment & 3.55 \\
\hline 24. & Relation to the environment & 4.04 & Free time & 3.22 \\
\hline 25. & Mental effort & 4.03 & Recognition & 3.18 \\
\hline 26. & Prestige & 3.99 & Mission of the company & 3.17 \\
\hline 27. & Mission of the company & 3.99 & Personal growth & 3.15 \\
\hline 28. & Competences & 3.97 & Base salary & 3.09 \\
\hline 29. & Region's development & 3.94 & Mental effort & 3.01 \\
\hline 30. & Physical effort at work & 3.93 & Region's development & 2.95 \\
\hline
\end{tabular}

Source: Own research

Table 4 further defines the frequency of the analyzed samples, the average values of the motivational preferences in 2017 and 2018, the standard deviation and the p-level. Statistically significant differences are highlighted in bold. Significant changes in motivational preferences $(\mathrm{p}<0.05)$ occur with factors such as name of the company, prestige, selfactualization, fair appraisal system, mental effort, mission of the company, region's development, personal growth, relation to the environment, free time, recognition and base salary. Figures 3 to 14 illustrate significantly different motivational preferences. 
ENTREPRENEURSHIP AND SUSTAINABILITY ISSUES

ISSN 2345-0282 (online) http://jssidoi.org/jesi/

2019 Volume 6 Number 4 (June)

http://doi.org/10.9770/jesi.2019.6.4(5)
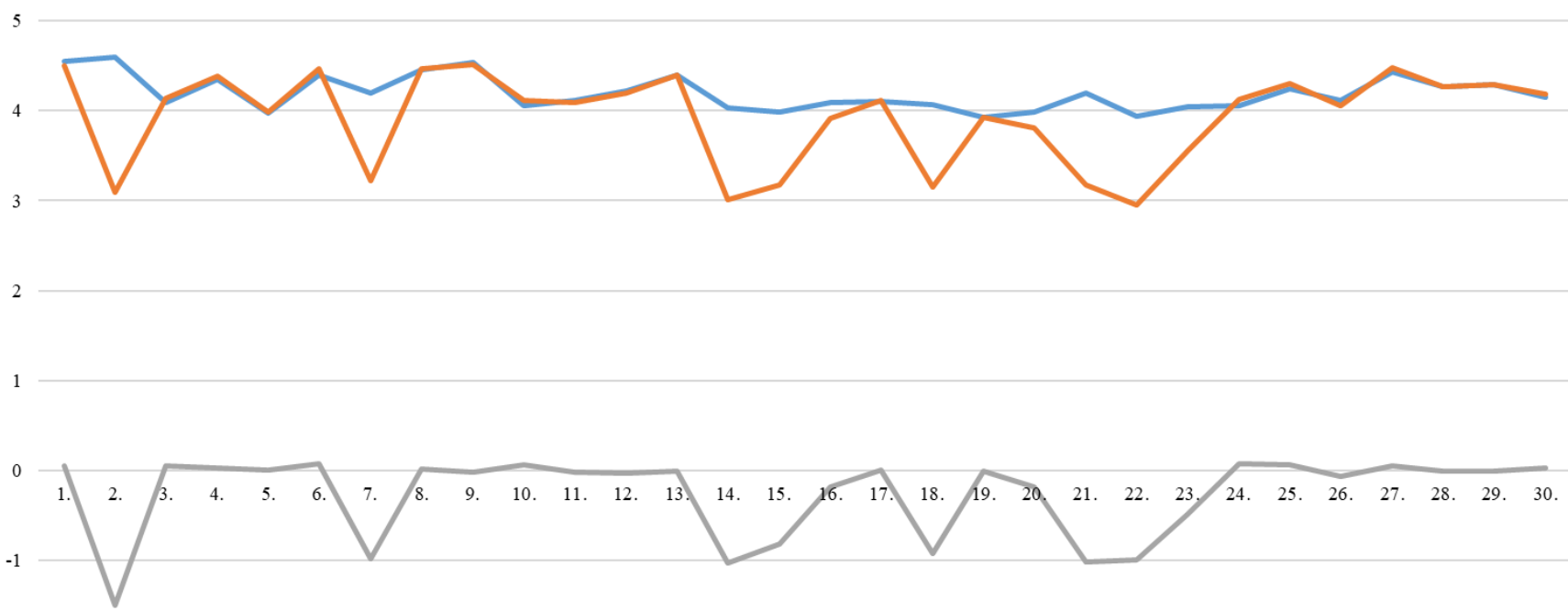

$-2$

$-2017-2018 \longrightarrow$ Difference

Fig.2. Comparison of motivational preferences of employees working in small enterprises in Slovakia in 2017 and 2018

Source: Own research

Table 4. Testing of motivational preferences of employees working in small enterprises in Slovakia in 2017 and 2018

\begin{tabular}{|c|c|c|c|c|c|c|c|c|c|}
\hline Motivational factors & $\begin{array}{c}\mathrm{N} \\
2018\end{array}$ & $\begin{array}{c}\mathbf{N} \\
2017 \\
\end{array}$ & $\begin{array}{c}\bar{x} \\
2018\end{array}$ & $\begin{array}{c}\bar{x} \\
2017\end{array}$ & $\begin{array}{c}S_{x} \\
2018 \\
\end{array}$ & $\begin{array}{c}\mathbf{S}_{\mathbf{x}} \\
2017 \\
\end{array}$ & $\mathbf{t}$ & $\mathbf{d f}_{\mathbf{f}}$ & p-level \\
\hline Atmosphere in the workplace & 1419 & 1227 & 4.50 & 4.55 & 0.72 & 0.67 & 1.68 & 2644 & 0.093 \\
\hline Good work team & 1419 & 1227 & 4.51 & 4.53 & 0.73 & 0.68 & 0.85 & 2644 & 0.397 \\
\hline Fringe benefits & 1419 & 1227 & 4.47 & 4.45 & 0.75 & 0.75 & -0.57 & 2644 & 0.571 \\
\hline Physical effort at work & 1419 & 1227 & 3.92 & 3.93 & 0.92 & 0.98 & 0.47 & 2644 & 0.641 \\
\hline Job security & 1419 & 1227 & 4.39 & 4.40 & 0.81 & 0.78 & 0.39 & 2644 & 0.699 \\
\hline Communication in the $\mathrm{w}$ & 1419 & 1227 & 4.38 & 4.35 & 0.81 & 0.76 & -1.04 & 2644 & 0.300 \\
\hline Name of the company & 1419 & 1227 & 3.91 & 4.09 & 1.11 & 0.93 & 4.55 & 2644 & 0.000 \\
\hline Opportunity to apply one's own ability & 1419 & 1227 & 4.11 & 4.10 & 0.85 & 0.89 & -0.27 & 2644 & 0.786 \\
\hline Workload and type of work & 1419 & 1227 & 4.18 & 4.15 & 0.84 & 0.83 & -0.72 & 2644 & 0.471 \\
\hline Information about performan & 1419 & 1227 & 4.09 & 4.11 & 0.92 & 0.89 & 0.66 & 2644 & 0.509 \\
\hline Working hours & 1419 & 1227 & 4.29 & 4.29 & 0.86 & 0.82 & -0.08 & 2644 & 0.933 \\
\hline Work environm & 1419 & 1227 & 4.26 & 4.26 & 0.85 & 0.77 & 0.22 & 2644 & 0.826 \\
\hline Job performance & 1419 & 1227 & 4.19 & 4.22 & 0.82 & 0.83 & 0.86 & 2644 & 0.389 \\
\hline Career advanceme & 1419 & 1227 & 4.14 & 4.09 & 0.84 & 0.88 & -1.41 & 2644 & 0.159 \\
\hline Competences & 1419 & 1227 & 3.98 & 3.97 & 1.00 & 0.91 & -0.35 & 2644 & 0.726 \\
\hline Prestige & 1419 & 1227 & 3.81 & 3.99 & 1.06 & 0.88 & 4.68 & 2644 & 0.000 \\
\hline Supervisor's approach & 1419 & 1227 & 4.48 & 4.43 & 0.82 & 0.77 & -1.82 & 2644 & 0.069 \\
\hline Individual decision-making & 1419 & 1227 & 4.11 & 4.05 & 0.89 & 0.85 & -1.78 & 2644 & 0.075 \\
\hline Selfactualization & 1419 & 1227 & 4.13 & 4.05 & 0.87 & 0.86 & -2.47 & 2644 & 0.014 \\
\hline Social benefits & 1419 & 1227 & 4.30 & 4.24 & 0.80 & 0.84 & -1.61 & 2644 & 0.108 \\
\hline Fair appraisal s & 1419 & 1227 & 4.47 & 4.39 & 0.75 & 0.80 & -2.60 & 2644 & 0.009 \\
\hline Stress & 1419 & 1227 & 4.05 & 4.11 & 0.95 & 0.88 & 1.65 & 2644 & 0.099 \\
\hline Mental effort & 1419 & 1227 & 3.01 & 4.03 & $\mathbf{1 . 0 8}$ & 0.90 & 26.28 & 2644 & 0.000 \\
\hline Mission of the company & 1419 & 1227 & 3.17 & 3.99 & 0.98 & $\mathbf{0 . 9 3}$ & 21.75 & 2644 & 0.000 \\
\hline Region's development & 1419 & 1227 & 2.95 & 3.94 & 1.04 & 0.99 & 25.10 & 2644 & 0.000 \\
\hline
\end{tabular}




\section{ENTREPRENEURSHIP AND SUSTAINABILITY ISSUES}

ISSN 2345-0282 (online) http://jssidoi.org/jesi/

2019 Volume 6 Number 4 (June)

http://doi.org/10.9770/jesi.2019.6.4(5)

\begin{tabular}{|l|l|l|l|l|l|l|l|l|l|}
\hline Personal growth & 1419 & 1227 & 3.15 & 4.07 & 1.11 & $\mathbf{0 . 9 2}$ & $\mathbf{2 3 . 0 0}$ & $\mathbf{2 6 4 4}$ & $\mathbf{0 . 0 0 0}$ \\
\hline Relation to the environment & 1419 & 1227 & 3.55 & 4.04 & 1.13 & $\mathbf{1 . 0 0}$ & $\mathbf{1 1 . 7 4}$ & $\mathbf{2 6 4 4}$ & $\mathbf{0 . 0 0 0}$ \\
\hline Free time & 1419 & 1227 & $\mathbf{3 . 2 2}$ & $\mathbf{4 . 2 0}$ & $\mathbf{1 . 1 2}$ & $\mathbf{0 . 8 7}$ & $\mathbf{2 4 . 9 8}$ & $\mathbf{2 6 4 4}$ & $\mathbf{0 . 0 0 0}$ \\
\hline Recognition & 1419 & 1227 & $\mathbf{3 . 1 8}$ & $\mathbf{4 . 1 9}$ & $\mathbf{1 . 0 6}$ & $\mathbf{0 . 8 6}$ & $\mathbf{2 6 . 5 2}$ & $\mathbf{2 6 4 4}$ & $\mathbf{0 . 0 0 0}$ \\
\hline Base salary & 1419 & 1227 & $\mathbf{3 . 0 9}$ & $\mathbf{4 . 5 9}$ & $\mathbf{1 . 1 7}$ & $\mathbf{0 . 7 2}$ & $\mathbf{3 9 . 1 1}$ & $\mathbf{2 6 4 4}$ & $\mathbf{0 . 0 0 0}$ \\
\hline
\end{tabular}

Note: Statistically significant motivational factors are highlighted in bold.

Source: Own research

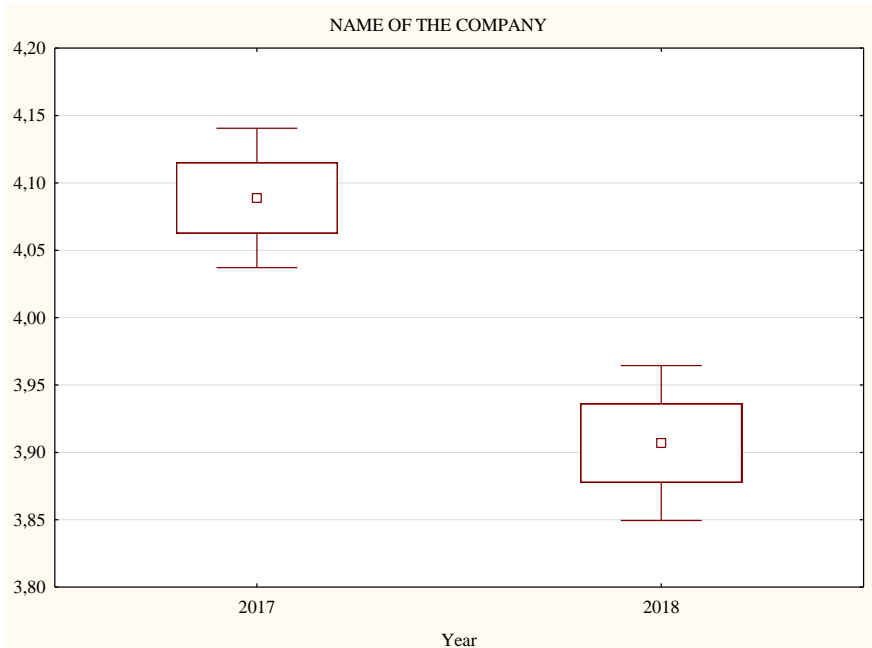

Fig.3. Motivational preferences of employees working in small enterprises in Slovakia in 2017 and 2018 - name of the company

Source: Own research

SELFACTUALIZATION

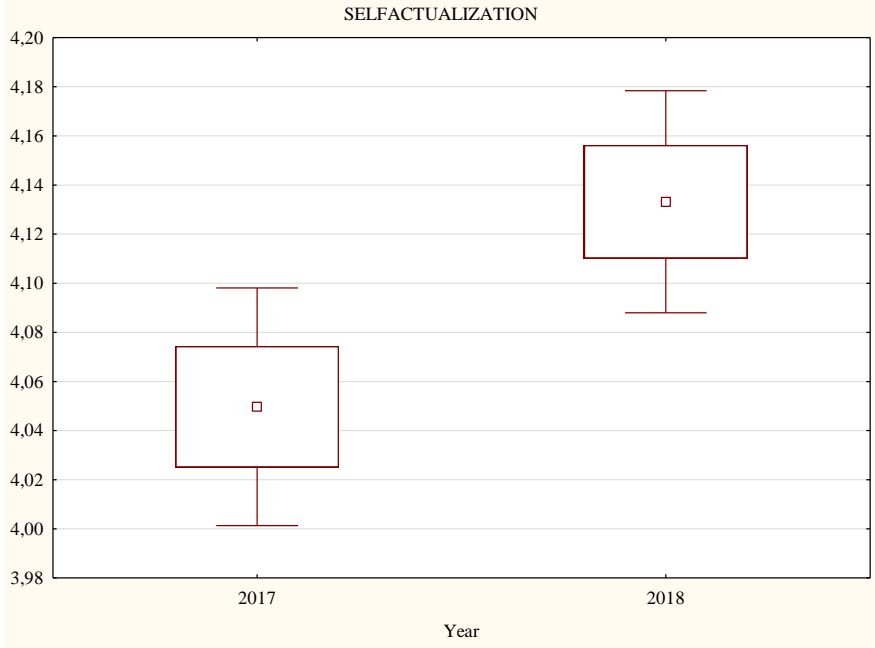

Fig.5. Motivational preferences of employees working in small enterprises in Slovakia in 2017 and 2018 - selfactualization

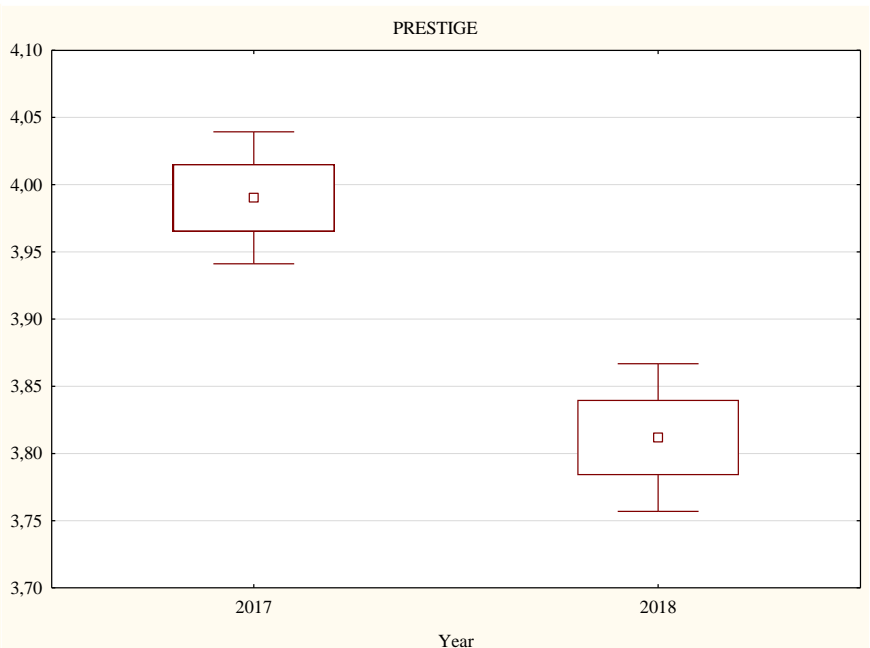

Fig.4. Motivational preferences of employees working in small enterprises in Slovakia in 2017 and 2018 - prestige

Source: Own research

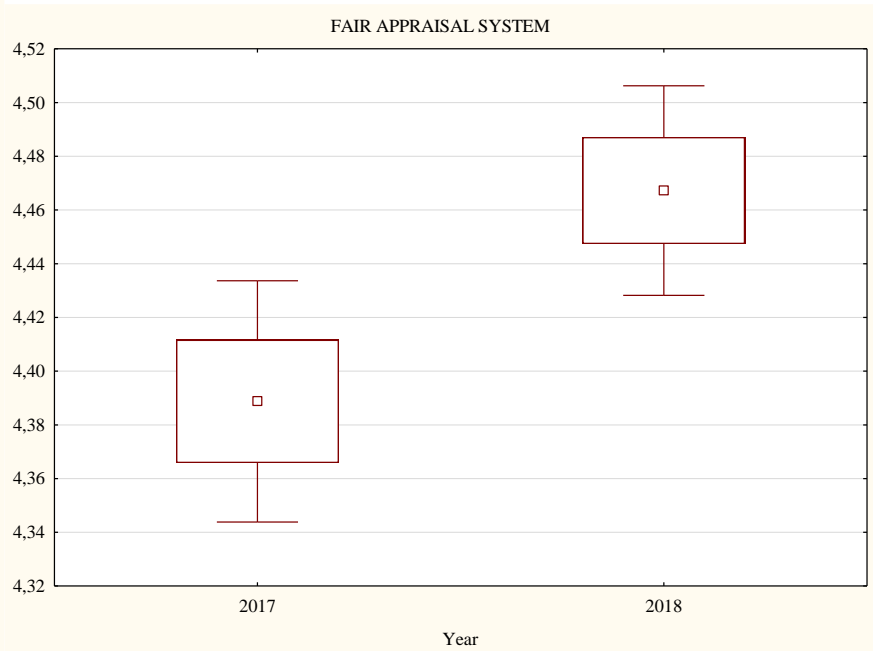

Fig.6. Motivational preferences of employees working in small enterprises in Slovakia in 2017 and 2018 - fair appraisal system 
ENTREPRENEURSHIP AND SUSTAINABILITY ISSUES

ISSN 2345-0282 (online) http://jssidoi.org/jesi/

2018 Volume 6 Number 4 (June)

http://doi.org/10.9770/jesi.2019.6.4(5)

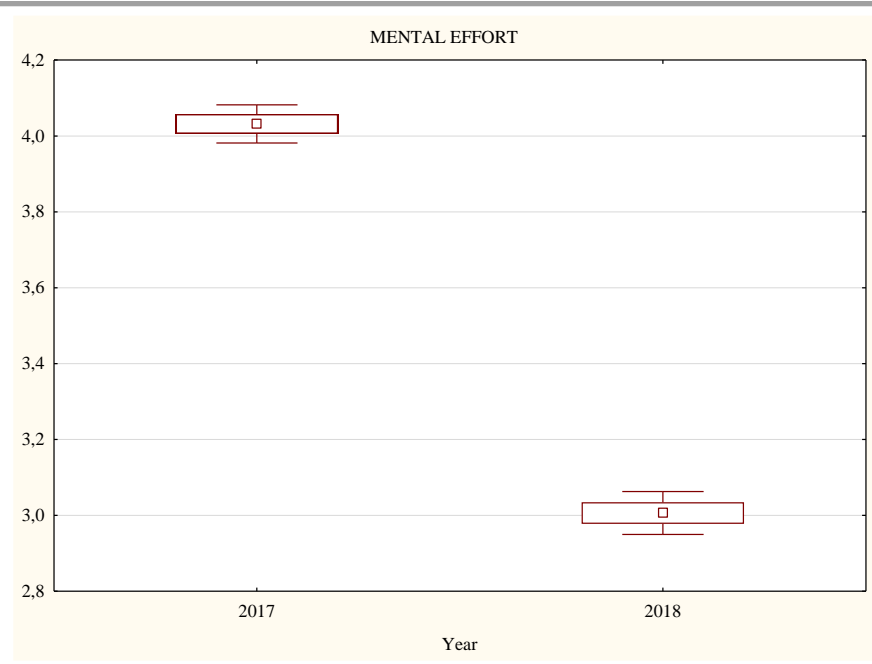

Fig.7. Motivational preferences of employees working in small enterprises in Slovakia in 2017 and 2018 - mental effort

Source: Own research

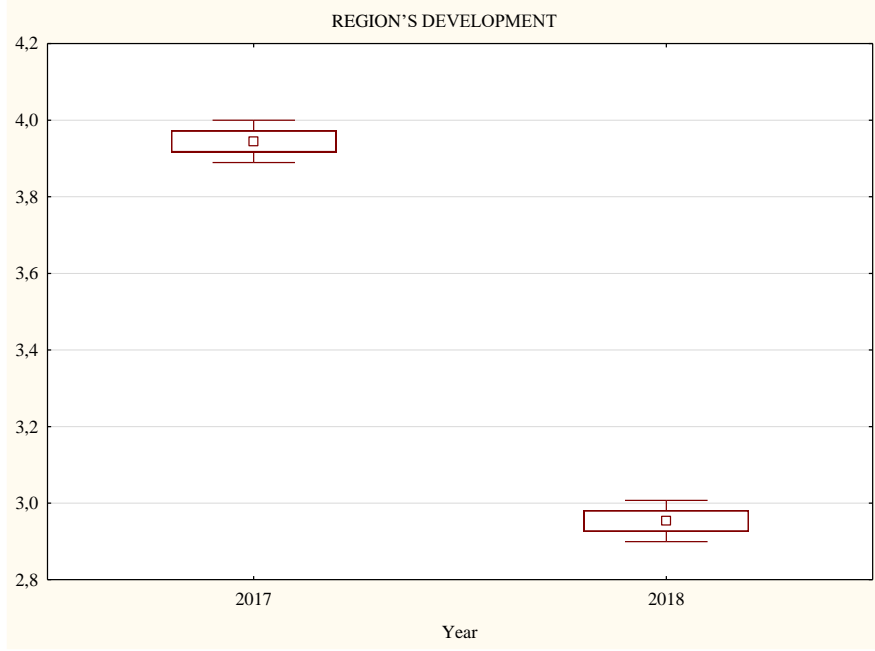

Fig.9. Motivational preferences of employees working in small enterprises in Slovakia in 2017 and 2018 - region's development

Source: Own research

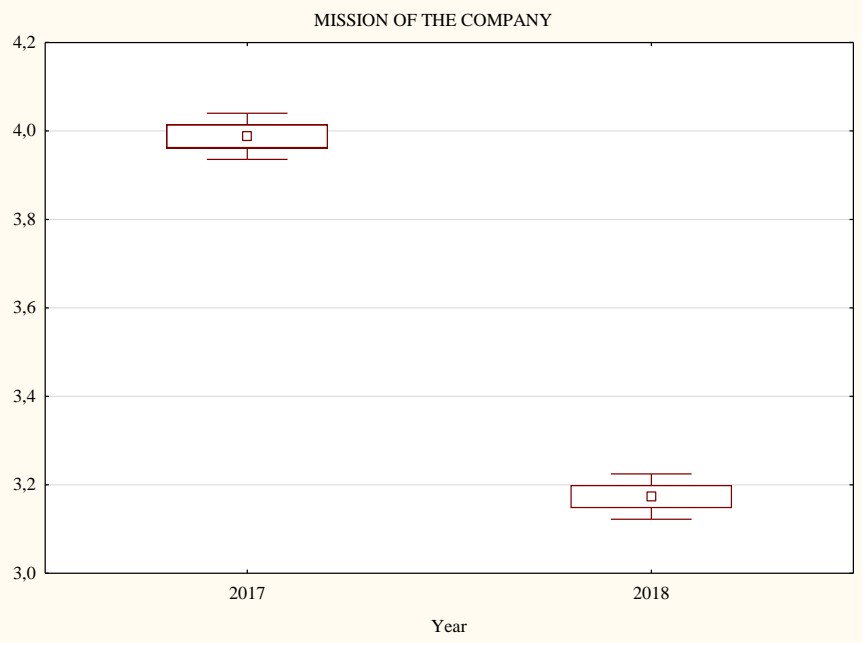

Fig.8. Motivational preferences of employees working in small enterprises in Slovakia in 2017 and 2018 - mission of the company

Source: Own research

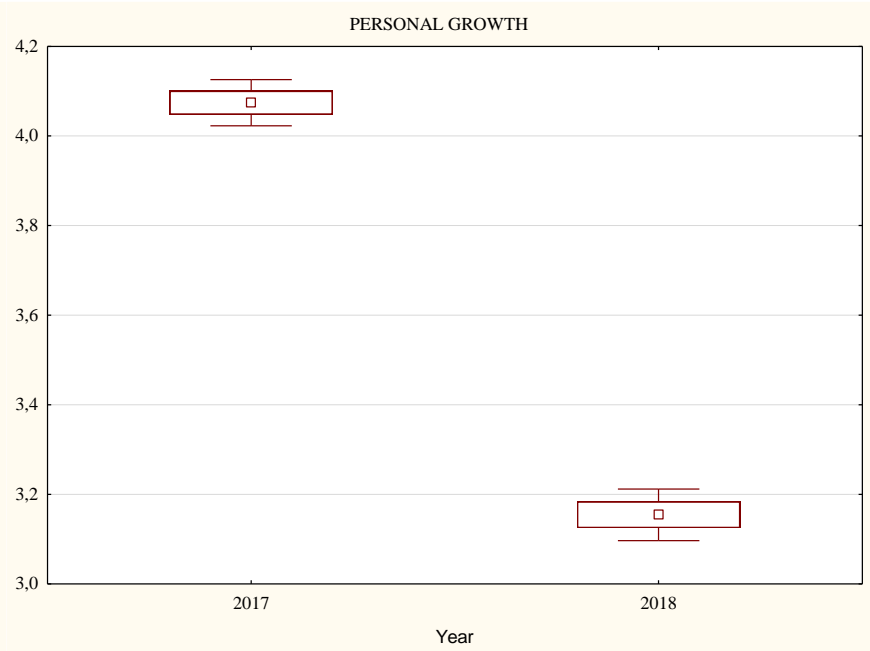

Fig.10. Motivational preferences of employees working in small enterprises in Slovakia in 2017 and 2018 - personal growth

Source: Own research 


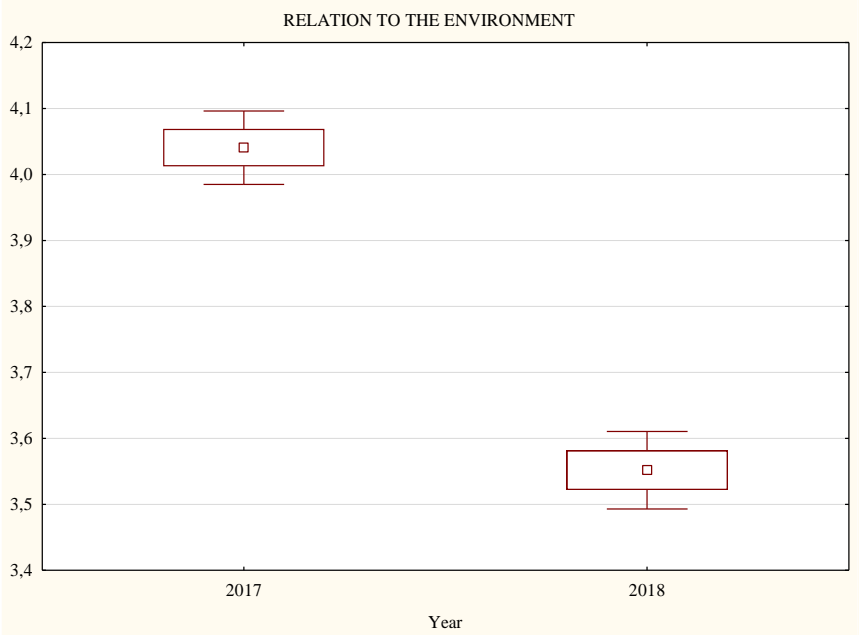

Fig.11. Motivational preferences of employees working in small enterprises in Slovakia in 2017 and 2018 - relation to the environment

Source: Own research

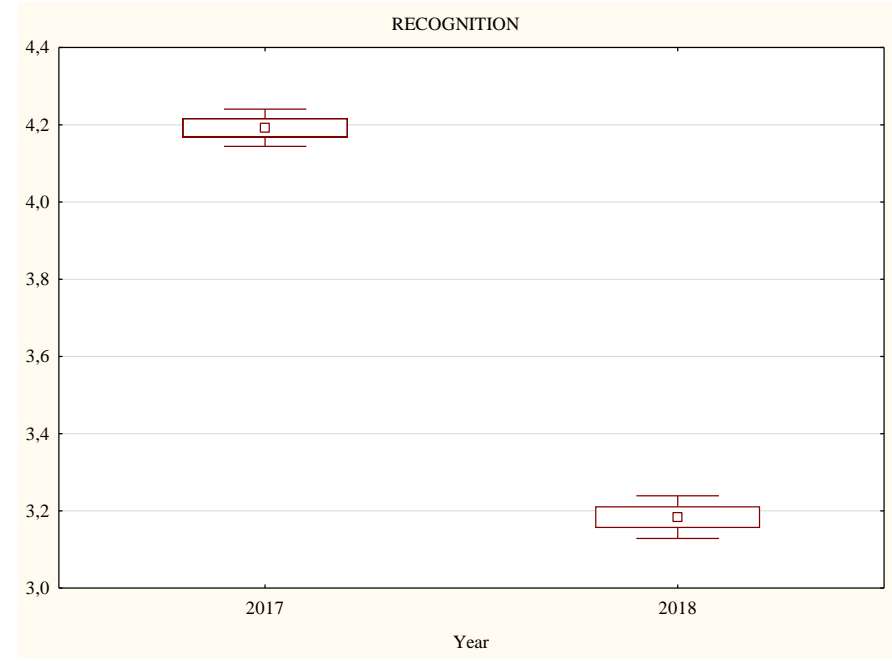

Fig.13. Motivational preferences of employees working in small enterprises in Slovakia in 2017 and 2018 - recognition

Source: Own research

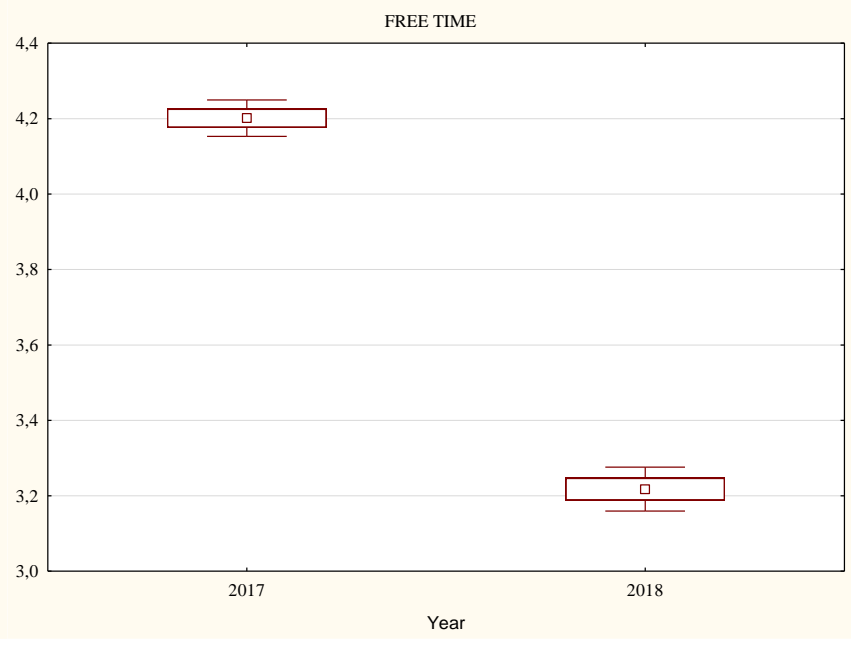

Fig.12. Motivational preferences of employees working in small enterprises in Slovakia in 2017 and 2018 - free time

Source: Own research

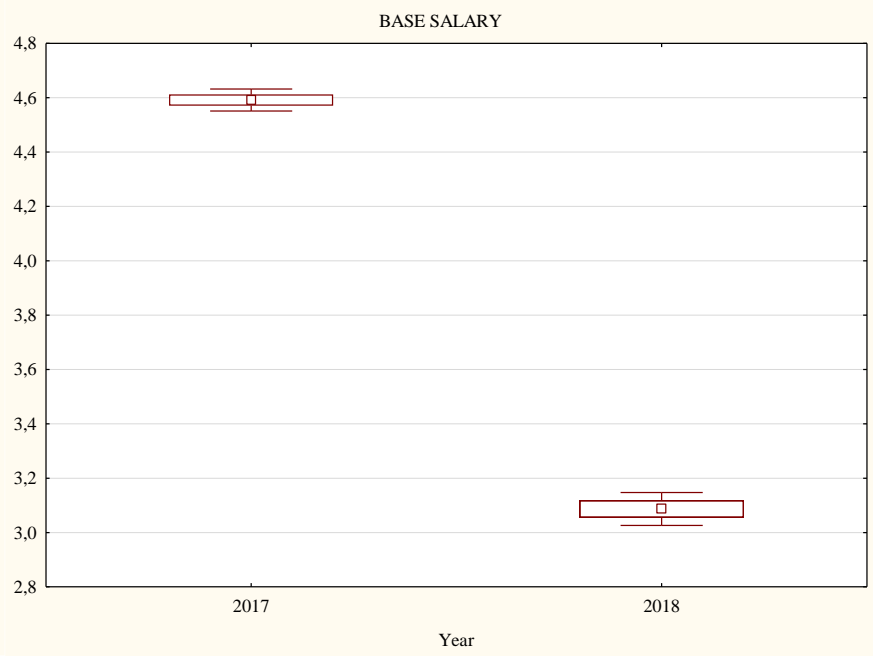

Fig.14. Motivational preferences of employees working in small enterprises in Slovakia in 2017 and 2018 - base salary

Source: Own research

Based on the research results, it can be said that motivational preferences of employees working in small enterprises in Slovakia change over time (within 1 year). This holds particularly true in the motivational preferences related to the social needs (mission of the company, name of the company, region's development, relation to the environment, free time). Considering the financial motivational preferences, the different factors are base salary and the fair appraisal system. In the motivational preferences related to the work there is a difference in the motivational factor mental effort. Based on the results, it can be said that our working hypothesis $\left(\mathrm{WH}_{1}\right)$ has not been confirmed, so that motivational preferences of employees working in small enterprises in Slovakia are changing over time. Our findings are consistent with the results of Armstrong (2007) research, which 
also stated that the set of motivational factors changes in time. The author cited identified several factors influencing the motivational preferences. It is knowledge, age, education, experience, surroundings, and so on.

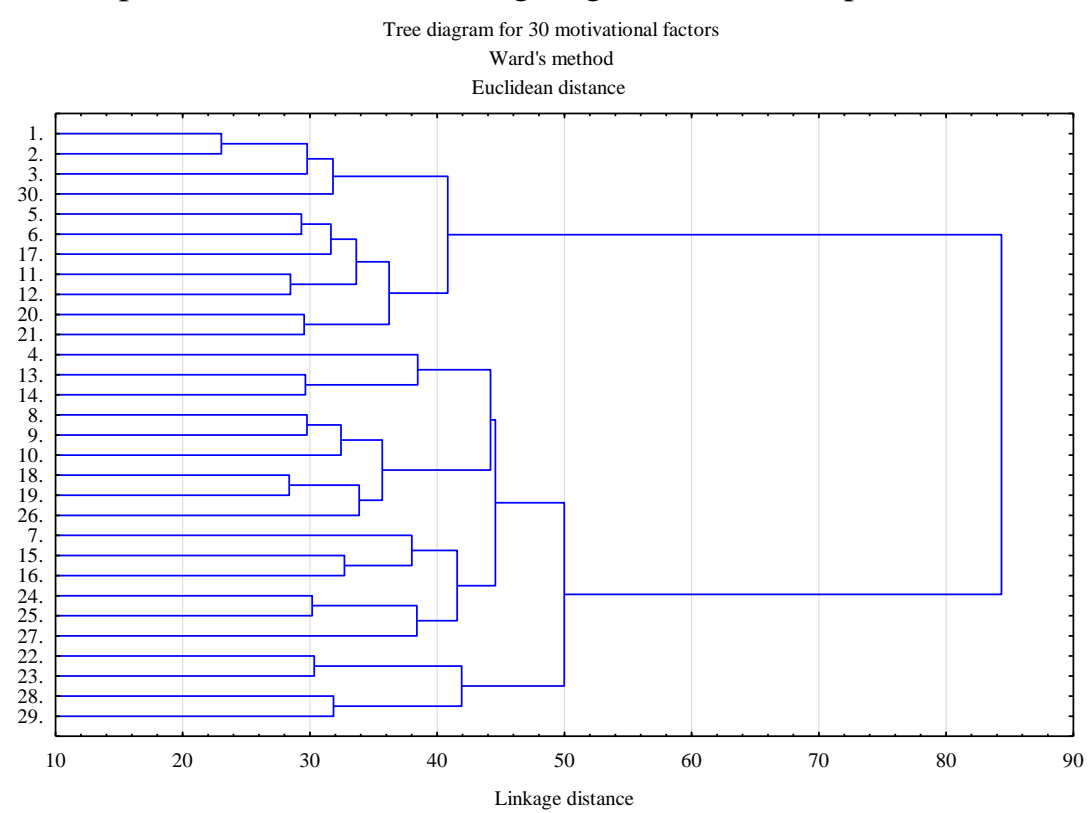

Fig.15. Cluster analysis for motivational preferences of employees working in small enterprises in Slovakia in 2017

Source: Own research

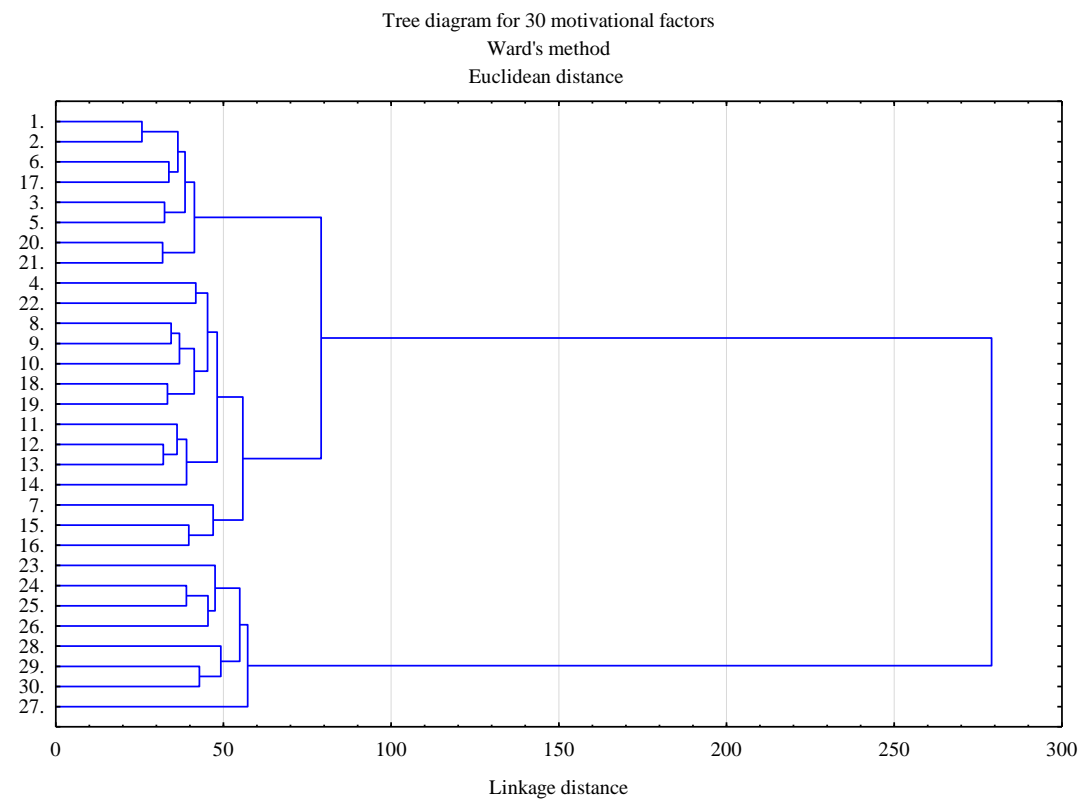

Fig.16. Cluster analysis for motivational preferences of employees working in small enterprises in Slovakia in 2018 Source: Own research 
ENTREPRENEURSHIP AND SUSTAINABILITY ISSUES

ISSN 2345-0282 (online) http://jssidoi.org/jesi/

2019 Volume 6 Number 4 (June)

http://doi.org/10.9770/jesi.2019.6.4(5)

Table 5. Distinguishing the groups of motivational factors preferred by employees working in small enterprises in Slovakia in 2017 and 2018

\begin{tabular}{|c|c|c|c|c|c|c|c|}
\hline \multicolumn{4}{|c|}{2017} & \multicolumn{4}{|c|}{2018} \\
\hline & No. & Motivational factors & relating to & & No. & Motivational factors & relating to \\
\hline \multirow{11}{*}{$\begin{array}{l}\vec{O} \\
\text { Oें }\end{array}$} & 1. & Atmosphere in the workplace & mutual relationship & \multirow{8}{*}{ Z0 } & 1. & Atmosphere in the workplace & mutual relationship \\
\hline & 2. & Good work team & mutual relationship & & 2. & Good work team & mutual relationship \\
\hline & 3. & Fringe benefits & finance & & 6. & Communication in the workplace & mutual relationship \\
\hline & 30. & Base salary & finance & & 17. & Supervisor's approach & mutual relationship \\
\hline & 5. & Job security & work condition & & 3. & Fringe benefits & finance \\
\hline & 6. & Communication in the workplace & mutual relationship & & 5. & Job security & work condition \\
\hline & 17. & Supervisor's approach & mutual relationship & & 20. & Social benefits & social needs \\
\hline & 11. & Working hours & work condition & & 21. & Fair appraisal system & finance \\
\hline & 12. & Work environment & work condition & \multirow{14}{*}{ 芌 } & 4. & Physical effort at work & work condition \\
\hline & 20. & Social benefits & social needs & & 22. & Stress & work condition \\
\hline & 21. & Fair appraisal system & finance & & 8. & Opportunity to apply one's own ability & career aspiration \\
\hline \multirow{9}{*}{ 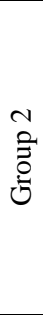 } & 4. & Physical effort at work & work condition & & 9. & Workload and type of work & work condition \\
\hline & 13. & Job performance & work condition & & 10. & Information about performance result & work condition \\
\hline & 14. & Career advancement & career aspiration & & 18. & Individual decision-making & career aspiration \\
\hline & 8. & Opportunity to apply one's own ability & career aspiration & & 19. & Selfactualization & career aspiration \\
\hline & 9. & Workload and type of work & work condition & & 11. & Working hours & work condition \\
\hline & 10. & Information about performance result & work condition & & 12. & Work environment & work condition \\
\hline & 18. & Individual decision-making & career aspiration & & 13. & Job performance & work condition \\
\hline & 19. & Selfactualization & career aspiration & & 14. & Career advancement & career aspiration \\
\hline & 26. & Personal growth & career aspiration & & 7. & Name of the company & social needs \\
\hline \multirow{10}{*}{$\begin{array}{l}\text { m } \\
\text { Oे } \\
0 \\
0\end{array}$} & 7. & Name of the company & social needs & & 15. & Competences & career aspiration \\
\hline & 15. & Competences & career aspiration & & 16. & Prestige & career aspiration \\
\hline & 16. & Prestige & career aspiration & \multirow{8}{*}{$\begin{array}{c}m \\
\hat{0} \\
0 \\
\dot{0}\end{array}$} & 23. & Mental effort & work condition \\
\hline & 24. & Mission of the company & social needs & & 24. & Mission of the company & social needs \\
\hline & 25. & Region's development & social needs & & 25. & Region's development & social needs \\
\hline & 27. & Relation to the environment & social needs & & 26. & Personal growth & career aspiration \\
\hline & 22. & Stress & work condition & & 28. & Free time & social needs \\
\hline & 23. & Mental effort & work condition & & 29. & Recognition & career aspiration \\
\hline & 28. & Free time & social needs & & 30. & Base salary & finance \\
\hline & 29. & Recognition & career aspiration & & 27. & Relation to the environment & social needs \\
\hline
\end{tabular}

Source: Own research

Subsequently, using cluster analysis, the similar groups of motivational preferences of employees working in small enterprises in Slovakia in individual years were identified. Results are presented in Figure 15 and Figure 16. Following the results presented in Figure 15, Figure 16 and Table 5, it can be stated that in the two years analysed, it was possible to distinguish three similar groups of motivational preferences. The first group include motivational factors related to the mutual relationship and finance. The second group include motivational factors related to the work condition and career aspiration. The last group include motivational factors with the prevalence to social needs. Based on the research results, working hypothesis $\left(\mathrm{WH}_{2}\right)$ has been confirmed, so the groups of motivational factors preferred by employees working in small enterprises in Slovakia do not change over time.

Appropriately choosing motivational factors that lead employees to performance is the core role of managers because employee performance is reflected on the overall performance of an enterprise. Research by Hersey (2013) confirms the fact that if employees are motivated, they use their skills to 80 to $90 \%$. In the study by Kozjek and Ovsenik (2017), the authors confirmed the importance of positive motivation of employees in the enterprise. Their research has shown that motivation by management is a very important factor and concludes that the manager can influence employee motivation up to 46.7\%. Jeffrey and Shaffer (2007) dealt with the importance of motivational preferences. Research was conducted in India in 131 businesses in various areas of the private and public sectors. Businesses spent 1 billion USD to motivate employees, expecting job production to grow by $7 \%$ 


\section{ENTREPRENEURSHIP AND SUSTAINABILITY ISSUES}

ISSN 2345-0282 (online) http://jssidoi.org/jesi/

2019 Volume 6 Number 4 (June)

http://doi.org/10.9770/jesi.2019.6.4(5)

per year. The study revealed that in enterprises where motivational programs were introduced, production and productivity increased by an average of $41-61 \%$, with the exception of businesses experiencing a severe economic recession. The study confirmed the importance and effectiveness of motivation in the context of the growing performance of the company.

\section{Conclusions}

In today's economic conditions, it is essential for management to devote their attention to investing in human resources to increase employee performance (Fumasoli 2014; Hollenbeck et al. 2015; Mura, 2017; Alola et al. 2018; Černevičiūte et al. 2018; Moskalenko 2018). The management of the company is most involved in the management of work performance, then it is the middle management level, and, last but not least, the employees themselves follow. However, human resources are also indispensable in companies, and where management has understood their role, they are both the initiator and implementer of all performance enhancing tools that guarantee the competitiveness and economic success of the organization. Previous research (Demir et al. 2015; Mura et al. 2015; Ibidunni et al. 2016; Ližbetin et al. 2017; Sardak et al. 2017; Vydrová, 2018; Korauš et al. 2018; Sánchez-Sellero et al. 2018) have confirmed that overall enterprise performance is affected by employees and their motivation. Therefore, in this context, managers of Slovak small enterprises, when creating motivational programs, have to accept the fact that, due to the time, changes in motivation preferences of employees are taking place. If managers accept this change, they can encourage employees to perform better.

\section{References:}

Al-Belushi, F.; \& Rahman Khan, F. 2017. Impact of monetary incentives on employee's motivation: Shinas college of technology, Oman A case study, International Journal of Management, Innovation \& Entrepreneurial Research 3(1): 1-11.

Alola, U. V.; Avci, T.; \& Ozturen, A. 2018. Organization sustainability through human resource capital: The impacts of supervisor incivility and self-efficacy, Sustainability 10(8): 2610. https://doi.org/10.3390/su10082610

Altinay, L.; Madanoglu, M.; De Vita, G.; Arasli, H.; \& Ekinci, Y. 2016. The interface between organizational learning capability, entrepreneurial orientation, and SME growth, Journal of Small Business Management 54(3): 871-891. http://dx.doi.org/10.1111/jsbm.12219

Armstrong, M. 2007. Řizení lidských zdrojů. Praha: Published by Grada Publishing.

Aydın, A.; \& Tiryaki, S. 2018. Impact of performance appraisal on employee motivation and productivity in Turkish forest products industry: A structural equation modeling analysis, Drvna Industrija 69(2): 101-111. http://dx.doi.org/10.5552/drind.2018.1710

Bělohlávek, F. Jak řidit a vést lidi. Brno: Published by Computer Press.

Bielikova, T.; Cut, S.; \& Uradnicek, V. 2014. The influence of the definition of risky company on financial situation diagnostic models in Slovak dynamic economic environment. The 7th International Scientific Conference on "Managing and Modelling of Financial Risks": September 8-9, Ostrava, Czech Republic. 38-45.

Bogdanović, M.; Vetráková, M.; \& Filip, S. 2018. Dark triad characteristics between economics \& business students in Croatia \& Slovakia: What can be expected from the future employees? Entrepreneurship and Sustainability Issues 5(4): 967-991. https://doi.org/10.9770/jesi.2018.5.4(19)

Borisov, A.; Narozhnaia, D.; Tarando, E.; Vorontsov, A.; Pruel, N.; \& Nikiforova, O. 2018. Destructive motivation of personnel: A case study of Russian commercial companies, Entrepreneurship and Sustainability Issues 6(1): 253-267. https://doi.org/10.9770/jesi.2018.6.1(16)

Boye, E.; Mensah, K.; \& Amponsah-Tawiah, K. 2016. Employee motivation and work performance: A comparative study of mining companies in Ghana, Journal of Industrial Engineering and Management 9(2): 255-309. http://dx.doi.org/10.3926/jiem.1530 


\section{ENTREPRENEURSHIP AND SUSTAINABILITY ISSUES}

ISSN 2345-0282 (online) http://jssidoi.org/jesi/

2019 Volume 6 Number 4 (June)

http://doi.org/10.9770/jesi.2019.6.4(5)

Campbell, S.; Reeves, D.; Kontopantelis, E.; Middleton, E.; Sibbald, B.; \& Roland, M. 2007. Quality of primary care in England with the introduction of pay for performance, New England Journal of Medicine 357(2): 181-190. http://dx.doi.org/10.1056/NEJMsr065990

Carr, S. C.; Parker, J.; Arrowsmith, J.; Haar, J.; \& Jones, H. 2017. Humanistic management and living wages: A case of compelling connections? Humanistic Management Journal 1(2): 215-236. http://dx.doi.org/10.1007\%2Fs41463-016-0018-y

Carreras, A. B. L.; Arroyo, J. C.; \& Blanco, J. E. E. 2018. Influence of the strategic planning and the management skills as factors internal of business competitiveness of SME's, Contaduria y Administracion, Accounting and Management 63(3): 9-10. http://dx.doi.org/10.22201/fca.24488410e.2018.1085

Cseh Papp, I., Varga, E., Schwarczová L., \& Hajós, L. (2018). Public work in an international and Hungarian context. Central European Journal of Labour Law and Personnel Management, 1 (1), 6 - 15

Černevičiūtè, J.; \& Strazdas, R. 2018. Teamwork management in creative industries: factors influencing productivity, Entrepreneurship and Sustainability Issues 6(2): 503-516. https://doi.org/10.9770/jesi.2018.6.2(3)

Chang, P. Ch.; Wu, T.; Liu, \& Ch. L. 2018. Do high-performance work systems really satisfy employees? Evidence from China, Sustainability 10(10), 3360. https://doi.org/10.3390/su10103360

Christianson, J. B.; Leatherman, S.; \& Sutherland, K. 2008. Lessons from evaluations of purchaser pay-for-performance programs a review of the evidence, Medical Care Research and Review 65(Suppl. 6): 5S-35S. http://dx.doi.org/10.1177/1077558708324236

Damij, N.; Levnajić, Z.; Skrt, V. R.; \& Suklan, J. 2015: What motivates us for work? Intricate web of factors beyond money and prestige, PLoS ONE 10. http://dx.doi.org/10.1371/journal.pone.0132641

Demir, M.; Demir, S. S.; \& Nield, K. 2015. The relationship between person-organization fit, organizational identification and work outcoms, Journal of Business Economics and Management 16(2): 369-386. http://dx.doi.org/10.3846/16111699.2013.785975

Denhardt, R. B.; Denhardt, J. V., \& Aristogueta, M. P. 2013. Managing human behavior in public and nonprofit organizations. California, USA: Published by SAGE Publications.

Diaz-Fernandez, M.; Bornay-Barrachina, M.; \& Lopez-Cabrales, A. 2015. Innovation and firm performance: The role of human resource management practices, Evidence-based HRM 3(1): 64-80. http://dx.doi.org/10.1108/EBHRM-10-2012-0012

Dobre, O. I. 2013. Employee motivation and organizational performance, Reaser 5(1): 53.

Eisenberger, R.; \& Aselage, J. 2009. Incremental effects of reward on experienced performance pressure: Positive outcomes for intrinsic interest and creativity, Journal of Organizational Behavior 30(1): 95-117. http://dx.doi.org/10.1002/job.543

Fakhrutdinova, E.; Kolesnikova, J.; Yurieva, O.; \& Kamasheva, A. 2013. The commercialization of intangible assets in the information society, World Applied Sciences Journal 27: 82-86. http://dx.doi.org/10.5829/idosi.wasj.2013.27.emf.17

Fumasoli, T. 2014. Strategic management of academic human resources: A comparative analysis of flagship universities in Norway, Finland, Switzerland, and Austria, New Voices in Higher Education Research and Scholarship 18-37. http://dx.doi.org/10.4018/978-1$\underline{4666-7244-4 . c h 002}$

Georgiadis, A.; \& Pitelis, C. N. 2012. Human resources and SME performance in services: empirical evidence from the UK, International Journal of Human Resource Management 23(4):808-825. http://dx.doi.org/10.1080/09585192.2011.561236

Grossbart, S. R. 2006. What's the return? Assessing the effect of "pay-for-performance" initiatives on the quality of care delivery, Medical Care Research and Review 63(Suppl. 1): 29S-48S. http://dx.doi.org/10.1177/1077558705283643

Haar, J.; Carr, S. C.; Arrowsmith, J.; Parker, J.; Hodgetts, D.; Alefaio-Tugia S. A. 2018. Escape from working poverty: Steps toward sustainable livelihood, Sustainability 10, 4144. http://dx.doi.org/10.3390/su10114144

Havierniková, K.; Lemańska-Majdzik, A.; \& Mura, L. 2017. Advantages and disadvantages of the participation of SMEs in tourism clusters, Journal of Environmental Management and Tourism 8(6): 1205-1215. https://doi.org/10.14505//jemt.v8.6(22).07

Hersey, P.; Blanchard, K.; \& Johnson, D. 2013. Management of organizational behavior. Published by Pearson.

Herzberg, F. I. 1987. One more time: How do you motivate employees? Harvard Business Review 65(5): 109-120. 


\section{ENTREPRENEURSHIP AND SUSTAINABILITY ISSUES}

ISSN 2345-0282 (online) http://jssidoi.org/jesi/

2019 Volume 6 Number 4 (June)

http://doi.org/10.9770/jesi.2019.6.4(5)

Hollenbeck, J. R.; \& Jamieson, B. B. 2015. Human capital, social capital, and social network analysis: Implications for strategic human resource management, Academy of Management Perspectives 29(3): 370-385. http://dx.doi.org/10.5465/amp.2014.0140

Ibidunni, S.; Osibanjo, O.; Adeniji, A.; Salau, O. P.; \& Falola, H. 2016. Talent retention and organizational performance, Periodica Polytechnica Social and Management Sciences 24(1): 1-13. http://dx.doi.org/10.3311/PPso.7958

Jeffrey, S.; \& Shaffer, V. 2007. The motivational properties of tangible incentives. Compensation \& Benefits Review 39(3): 44-50. https://doi.org/10.1177/0886368707302528

Jonec, P.; Beynon, M. J.; Pickernell, D.; \& Packham, G. 2013. Evaluating the impact of different training methods on SME business performance, Environment and Planning C: Government and Policy 31(1): 56-81. http://dx.doi.org/10.1068/c12113b

Kamasheva, A. V.; Valeev E. R.; Yagudin, R. Kh.; \& Maksimova, K. R. 2015. Usage of gamification theory for increase motivation of employees, Mediterranean Journal of Social Sciences 6: 77-80. http://dx.doi.org/10.5901/mjss.2015.v6n1s3p77

Korauš, A.; Mazák, M.; \& Dobrovič, J. 2018. Quantitative analysis of the competitiveness of Benelux countries, Entrepreneurship and Sustainability Issues 5(4): 1069-1083. http://dx.doi.org/10.9770/jesi.2018.5.4(26)

Koval'ová, M.; Hvolková, L.; Klement, L.; \& Klementová, V. 2018. Innovation strategies in the Slovak enterprises, Acta Oeconomica Universitatis Selye 7(1): 79-89.

Kozjek, K.; \& Ovsenik, M. 2017. Model of knowledge management factors and their impact on the organizations' success, Organizacija 50(2):112-131. http://dx.doi.org/10.1515/orga-2017-0008

Kropivšek, J.; Jelačić, D.; \& Grošelj, P. 2011. Motivating employees of Slovenian and Croatian wood-industry companies in times of economic downturn, Drvna Industrija 62(2): 97-103. https://doi.org/10.5552/drind.2011.1040

Lesáková, L. 2012. The role of business incubators in supporting the SME start-up, Acta Polytechnica Hungarica 9(3): 85-95.

Lesáková, L.; Gundová, P.; Král, P., \& Ondrušová, A. 2017. Innovation leaders, modest innovators and non-innovative SMEs in Slovakia: Key factors and barriers of innovation activity, Organizacija 50(4): 325-338. http://dx.doi.org/10.1515/orga-2017-0024

Ližbetin, J.; \& Bartuška, L. 2017. The influence of human factor on congestion formation on urban roads, Procedia Engineering 187: 206211. http://dx.doi.org/10.1016/j.proeng.2017.04.366

Ližbetinová, L. 2017. Clusters of Czech consumers with focus on domestic brands. The 29th International Business Information Management Association Conference „Education Excellence and Innovation Management through Vision 2020: From Regional Development Sustainability to Global Economic Growth “: May 3-4, Vienna, Austria. 1703-1718.

Ližbetinová, L.; \& Farkasova, V. 2016. Librarians competencies in the global environment. The 16th International Scientific Conference on „, Globalization and its Socio-Economic Consequences “: October 5-6, Rajecke Teplice, Slovakia. 1204-1211.

Malá, D.; Sedliačiková, M.; Dušak, M.; Kaščáková, A.; Musová, Z.; \& Klementová, J. 2017. Green logistics in the context of sustainable development in small and medium enterprises, Drvna Industrija 68(1), 69-79. http://dx.doi.org/10.5552/drind.2017.1620

Marková, V.; Sedliačiková, M.; \& Gurova, D. H. 2016. The model of financial budgeting and planning for micro and small enterprises. The 16th International Scientific Conference on "Globalization and its Socio-Economic Consequences": October 5-6, Rajecke Teplice, Slovakia. 1305-1312.

Mason, R. D.; \& Lind, D. A. 1990. Statistical techniques in business and economics. Boston: Published by Irwin.

Matraeva, L.; Belyak, A.; \& Konov, A. 2018. Corporate culture key criteria and clustering, Journal of Applied Economic Sciences 13(1): $34-42$.

Mészáros, M. (2018). "Employing” of self-employed persons. Central European Journal of Labour Law and Personnel Management, 1 (1), $31-50$

Minárová, M. 2015. Managers in SMEs and their emotional abilities, Acta Oeconomica Universitatis Selye 4(1): 83-92.

Moskalenko, A. A. 2018. Methodological characteristics of the use of strategic analysis in HR-related decision-making, Academy of Strategic Management Journal 17(4): 1-7. 


\section{ENTREPRENEURSHIP AND SUSTAINABILITY ISSUES}

ISSN 2345-0282 (online) http://jssidoi.org/jesi/

2019 Volume 6 Number 4 (June)

http://doi.org/10.9770/jesi.2019.6.4(5)

Mura, L. 2017. Current situation in Family Businesses. Managerial trends in the development of enterprises in globalization era, pp. 178185.

Mura, L., \& Kljucnikov, A. 2018. Small Businesses in Rural Tourism and Agrotourism: Study from Slovakia. Economics \& Sociology, Vol. 11, No. 3, pp. 286-300. http://dx.doi.org/10.14254/2071-789X.2018/11-3/17

Mura, L.; \& Mazák, M. 2018. Innovative activities of family SMEs: Case study of the Slovak regions, Online Journal Modelling the New Europe 27: 132-147. http://dx.doi.org/10.24193/OJMNE.2018.27.06

Musa, H.; Debnárová, L.; Musová, Z.; \& Krištofík, P. 2017. Gender equality and corporate governance in Slovakia, E a M: Ekonomie a Management 20(1): 98-110. http://dx.doi.org/10.15240/tul/001/2017-1-007

Myint, S. S.; Leamprecha, N.; Pooncharoen, N.; \& Rurkwararuk, W. 2016. An analysis of employee satisfaction of private banks in Myanmar, International Business Management 10(2): 101-114. http://dx.doi.org/10.3923/ibm.2016.101.114

Nabi, N.; Ahmed, A. A. T.; \& Rahman, S. 2017. Empirical study on human resource management practices with special reference to job satisfaction and employee turnover at investment corporation of Bangladesh, Human Resource Management Research 7(1): 54-64. http://dx.doi.org/10.5923/j.hrmr.20170701.07

Němec, M.; Krišták, L'; Hockicko, P.; Danihelová, Z.; \& Velmovská, K. 2017. Application of innovative P\&E method at technical universities in Slovakia, Eurasia Journal of Mathematics Science and Technology Education 13: 2329-2349.

Pingping, S. 2017. Research on the innovation of enterprise employee incentive way management based on big data background, Agro Food Industry Hi-Tech 28(1): 1434-1438.

Poliačiková, E. 2015. Key accout management as a inovation form of entry to customers in Slovakia, Acta Oeconomica Universitatis Selye 4(1): 135-145.

Prange, C.; \& Pinho, J. C. 2017. How personal and organizational drivers impact on SME international performance: The mediating role of organizational innovation, International Business Review 26(6): 1114-1123. http://dx.doi.org/10.1016/j.ibusrev.2017.04.004

Salyova, S.; Taborecka-Petrovicova, J.; Nedelova, G.; \& Dado, J. 2015. Effect of marketing orientation on business performance: A study from Slovak foodstuff industry, Procedia Economics and Finance 34: 622-629. http://dx.doi.org/10.1016/S2212-5671(15)01677-9

Sánchez-Sellero, M. C.; Sánchez-Sellero, P.; Cruz-González, M. M.; \& Sánchez-Sellero, F. J. 2018. Determinants of job satisfaction in the Spanish wood and paper industries: A comparative study across Spain, Drvna Industrija 69(1): 71-80. http://dx.doi.org/10.5552/drind.2018.1711

Sardak, S.; Bilskaya, O.; \& Simakhova, A. 2017. Potential of economy socialisation in the context of globalisation, Economic Annals-XXI 164(3-4): 4-8. http://dx.doi.org/10.21003/ea.V164-01

Schouten, M.J. 2019. Undoing gender inequalities: insights from the Portuguese perspective, Insights into Regional Development (2): 8598. https://doi.org/10.9770/ird.2019.1.2(1)

Scheer, L.; \& Sedmák, R. 2014. Biometria. Zvolen: Published by Technická univerzita vo Zvolene.

Sertic, M. B.; Barcic, A. P.; \& Klaric, K. 2018. Economic determinants and analysis of the European Union wood industry SMEs employment, BioResources 13(1): 522-534. https://doi.org/10.15376/biores.13.1.522-534

Slovak Business Agency. 2018. Malé a stredné podnikanie v čislach v roku 2017. Retrieved from https://www.npc.sk/file?uuid=b40742beac93-4fd0-ae60-b52467626139

Straková, J.; Kucharčíková, A.; Pártlová, P.; \& Váchal, J. 2016. Foreign direct investment and transport serviceability - a prerequisite for the development and stability of national and regional economies, Nase More 63(3): 204-210. https://doi.org/10.17818/NM/2016/SI24

Triola, M. F. 1989. Elementary statistics. Redwood City: Published by The Benjamin/Cummings publishing Company.

Urbancová, H.; Stachová, K.; \& Stacho, Z. 2017. Using of performance appraisal methods in Czech and Slovak organisations, Quality Innovation Prosperity 21(3): 62-77. http://dx.doi.org/10.12776/QIP.V21I3.890 
Van Herck, P.; De Smedt, D.; Annemans, L.; Remmen, R.; Rosenthal, M. B.; \& Sermeus, W. 2010. Systematic review: Effects, design choices, and context of pay-for-performance in health care, BMC Health Services Research 10(1): 247-260. http://dx.doi.org/10.1186/1472$\underline{6963-10-247}$

Vetráková, M.; Ďurian, J.; Seková, M.; \& Kašćáková, A. 2016. Employee retention and development in pulp and paper companies, BioResources 11(4): 9231-9243. https://doi.org/10.15376/biores.11.4.9231-9243

Vydrová, J. 2018. Identification of key employee benefits relating to employee satisfaction in selected health organizations in the Czech Republic. Acta Oeconomica Universitatis Selye 7(2), 175 - 187

Wang, W. T. 2016. Examining the influence of the social cognitive factors and relative autonomous motivations on emploeyees' knowledge sharing behaviors, Decision Sciences 47(3): 404-436.

Weihrich, H.; \& Koontz, H. 1993. Management. Praha: Published by VICTORIA Publishing.

Xu, Y.; Wang, Y.; Tao, X.; \& Ližbetinová, L. 2017. Evidence of Chinese income dynamics and its effects on income scaling law, Physica A: Statistical Mechanics and its Applications 487: 143-152. http://dx.doi.org/10.1016/j.physa.2017.06.020

Žulová, J., Švec, M., \& Madleňák, A. (2018). Personality aspects of the employee and their exploration from the GDPR perspective. Central European Journal of Labour Law and Personnel Management, 1(1); 51 -60

\section{Aknowledgements}

This research was supported by the project, which has received funding from VEGA 1/0024/17 Computational model of motivation. This research was supported by the project APVV 16-0297 Updating of anthropometric database of Slovak population, and VEGA 1/0320/17 Economic and social context of European 20/20/20 targets from the viewpoint of economy low-energy houses.
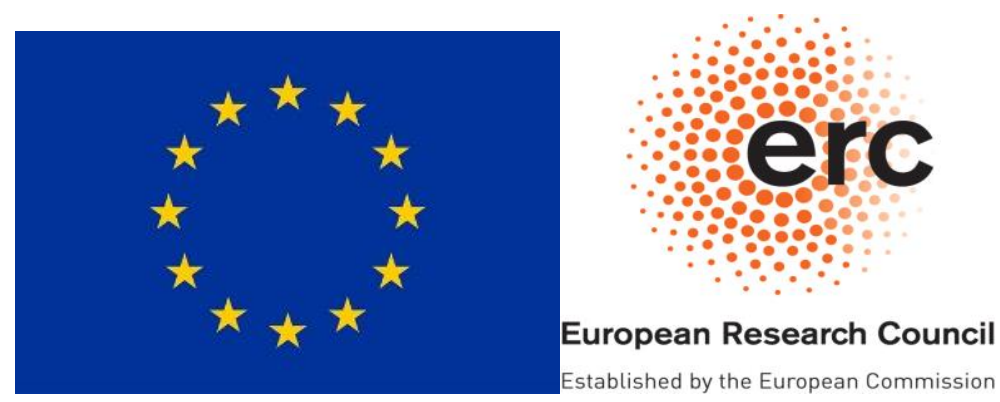
ENTREPRENEURSHIP AND SUSTAINABILITY ISSUES

ISSN 2345-0282 (online) http://jssidoi.org/jesi/

2019 Volume 6 Number 4 (June)

http://doi.org/10.9770/jesi.2019.6.4(5)

Silvia LORINCOVÁ is an Assistant Professor at Faculty of Wood Science and Technology, Technical University in Zvolen, Zvolen, Slovakia. She deals with the issue of Human Resources Management. She is the author of many articles published in database CCC, Web of Science and SCOPUS.

ORCID ID: orcid.org/0000-0002-5763-5002

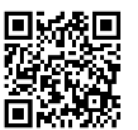

Miloš HITKA is an Associate Professor at Faculty of Wood Science and Technology, Technical University in Zvolen, Zvolen, Slovakia. His research interests are in the area of Human Resources Management. He is a Member of Editorial Boards for International Data Bases indexed Journals and the Organizing Committee of International Conferences. He is the author of many articles published in database CCC, Web of Science and SCOPUS.

ORCID ID: orcid.org/0000-0002-6567-7333

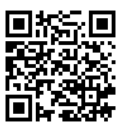

Lubica BAJZÍKOVÁ is a Professor at Faculty of Management, Comenius University in Bratislava. Her professional specialization is in current trends in Human Resource Management, employee compensation systems and motivation, workforce mobility, social partnerships, and organizational culture. She is the author of many articles published in database CCC, Web of Science and SCOPUS.

ORCID ID: orcid.org/0000-0001-6286-470X

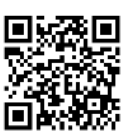

Dagmar WEBEROVÁ is an Associate Professor at the Faculty of Multimedia Communications, Tomas Bata University in Zlin. Her research interests are in the area of branding, brand awareness, design perception, employee motivation, and cross-cultural marketing. She is the author of many articles published in the Web of Science and SCOPUS databases.

ORCID ID: orcid.org/0000-0003-1483-0323

Copyright (C) 2019 by author(s) and VsI Entrepreneurship and Sustainability Center

This work is licensed under the Creative Commons Attribution International License (CC BY).

http://creativecommons.org/licenses/by/4.0/

cC) (i) Open Access 